\title{
Alone inside: solitary confinement and the ontology of the individual in modern life
}

\author{
B. Story \\ Department of Geography and Program in Planning University of Toronto, Toronto, Canada \\ Correspondence to: B. Story (brett.story@utoronto.ca)
}

Received: 4 March 2014 - Revised: 20 May 2014 - Accepted: 28 May 2014 - Published: 22 December 2014

\begin{abstract}
The long-term solitary confinement of prisoners causes fundamentally debilitative psychological damage. This violence, inherent to the socio-spatial organization of solitary confinement, diminishes prisoners' capacity to function as human beings. Yet while violence might characterize the ends of solitary confinement, individuation defines the means. This paper argues that solitary confinement, while an extreme case, shares crucial characteristics with other spaces, structures, and modes of organization familiar to Western society. The actual experiences of prisoners subjected to conditions of total isolation, moreover, contradict the prevailing ontology of the individuated subject. The irreconcilability of this paradox invites inquiry into the political and material problematic of individualism itself. The violence of solitary confinement's spatial practice therefore holds important implications for a critical reassessment of any or all socially isolating institutions and individuating ideologies within the structural fabric of modern life.
\end{abstract}

\section{Introduction}

In July 2013, some 30000 prisoners of California's penitentiary system participated in the largest hunger strike in state history. They were protesting the practice of long-term solitary confinement and its limitless dominion over the lives of thousands of Californian prisoners. The strike was a renewal, as well as an elaboration, of two similar hunger strikes in 2011. That year, about 12000 prisoners across more than a dozen institutions had used one of the last powers available to them in their austere conditions - the power to stop eating - to draw public attention to the problem of prison isolation.

At the California Assembly Public Safety Committee Hearing (2013) on proposed reforms to the Security Housing Unit (SHU) of the California Department of Correction and Rehabilitation (CDCR) in February of 2013, a handful of community members were given the opportunity to give testimonies on the effects of isolation on their family members and loved ones. First to speak was Irene Huerta, a wife of a prisoner at Pelican Bay's SHU. Huerta read a statement describing isolation written by her husband, who has been in solitary confinement since 1986 because of an alleged though unseen - memorandum connecting him to a prison gang:
It is like being locked in the trunk of a car with just enough weatherstripping removed so you can breathe, and with enough food and water stuffed in everyday inside so that you can physically survive. You're soon going to realize what it actually means when it's said that we're social beings. You're going to crave social interaction and human contact. Soon you're just hollering out there, you can talk even for a brief time ... And yet every time you talk, every time you act like a human being and interact with other human beings, you're told that it's a gang activity and you have to stay another 6 years now before your next review.

"You're soon going to realize what it actually means when it's said that we're social beings." Indeed, this realization is remarkable for being a deeply existential, as well as devastating one. Prisoners living in solitary confinement often describe encountering a state of "breaking down", or fighting to resist an impending "brokenness" that they can feel the isolation induce. Testimonies culled from the tens of thousands of US prisoners subjected to long-term isolation describe "the brain slowing to standstill," and "losing the ability to initiate any kind of action or behavior" (interviews with author, 
2011, 2012), and they find disturbing corroboration in the clinical findings on isolation's psychological consequences.

The bulk of research on solitary confinement over the long term paints a harrowing picture of its debilitating and psychologically damaging effects (see Grassian, 2006; Haney, 2003; Smith, 2006). The "breaking" is more literal than figurative: in the absence of meaningful human interaction, otherwise healthy prisoners begin to lose touch with reality. They have hallucinations and become paranoid. They become unable to distinguish sounds and images in their heads from those in actuality. Agitation, delirium, impulsive and self-destructive behavior, and acute psychosis have all been recorded as the consistent and predictable consequences of subjection to long-term sensory deprivation and social isolation (Grassian, 2006: 338; Smith, 2006: 457).

This paper suggests that the experiences of prisoners inside long-term isolation in fact have tremendous implication for how we consider and organize social life on the outside of prison structures. Specifically, it uses the material experiences of spatially isolated prisoners to pose a speculative, but politically significant, challenge to the very ontology of the individual subject in modern life. For if it is indeed the spatial practice of socially isolating, or, to use Michel Foucault's description, "individualizing" (Foucault, 1977: 236) prisoners that is the cause of such damage, we are presented with an interesting pair of questions: What is this self that can be broken? And how does it compare to the atomized individual subject that organizes and structures everyday life in the liberal, capitalist West?

It is the ontology of the atomized individual as such, the historical conditions of its possibility, and its contemporary economic and political salience against which this paper seeks to situate the practice and consequences of solitary confinement. In other words, this paper explores what the carceral practice of solitary confinement discloses and disturbs about the very idea of the individual subject as a category of being. I will begin by demonstrating that in both its historical antecedents and its contemporary resurgence within the US prison system, the penal practice of solitary confinement is characterized fundamentally by conditions of extreme social individuation. That this carceral practice of individuation constitutes a form of violence is the premise upon which I make a case for investigating the very ontology of the individual, and the ideological practices it animates in non-carceral modern life, as itself a form of violence.

The 18th century origins of solitary confinement will be considered in the context of the Enlightenment period and the political conditions the Enlightenment helped lay for the individuated subject as a theory of being - an ontology that far outlasted the earliest iterations of penal isolation as an experiment in rehabilitation. There is an important contradiction, I'll argue, between the actual experiences of prisoners subjected to conditions of total isolation, and the orthodoxy of individuated subjectivity that animates the dominating structures and modalities of modern life. The irreconcilability of this paradox, I suggest, offers us important insight into the political and material problematic of individualism itself.

\section{Solitary confinement in the 19th century: ideals and realities}

The US prison population exploded from around 300000 people in 1973 to nearly 2.4 million in 2010 . This unprecedented phenomenon of prison expansion over less than 40 years has become widely known as mass incarceration, and a significant body of literature has attended, from a variety of disciplinary perspectives, to the challenge of explaining and interpreting it (see for example Garland, 2001; Gilmore, 2007; Gottschalk, 2007; Mauer, 2006; Perkinson, 2010; Wacquant, 2009). The US now not only has the highest rate of incarceration in the world, but the lock-up boom has profoundly racialized contours. As Michelle Alexander points out, "the US imprisons a larger percentage of its black population than South Africa did at the height of apartheid. One in three young African-American men is currently under the control of the criminal justice system: in prison, in jail, on probation or on parole" (2009: 6-8).

Trending alongside this dramatic explosion is another, less explored phenomenon: the growing isolation of prisoners within these institutions themselves. In the US today not only are more people sentenced to more time in more prisons, but they are also in greater isolation than at any other time in its history. According to the 2005 census by the US Bureau of Justice, approximately 82000 people are reportedly confined in segregation units in the nation's prisons on any given day (Gibbons and Katzenbach, 2006). This number does not include the some 25000 prisoners held in isolation in super-maximum (supermax) facilities. Other estimates of the number of prisoners in solitary confinement are as high as 100000 or 120000 (Casella and Ridgeway, 2010).

Many of these prisoners spend years, or even decades, in the "management control units", "departmental disciplinary units" and "closed custody units" that constitute and euphemize the contemporary practice of solitary confinement. That confinement is typically characterized by holding prisoners alone at least $23 \mathrm{~h}$ per day, in cells averaging $6 \mathrm{ft}$ by $9 \mathrm{ft}$ with no opportunity for human contact or communication (Kamel and Kerness, 2003: 5). The cells are arranged so that prisoners have no view of one another. The spaces themselves are often stark, with a sterile and monotonous arrangement in keeping with the extreme restriction of sensory stimulation. Cells rarely have windows or other sources of natural light, air flow, or indicators of the passage of time. It is common to find artificial lights kept turned on $24 \mathrm{~h}$ a day (Shalev, 2011: 153).

The evidence of solitary confinement's intractable harm to the psyche of its human subjects is so great that it has been deemed by all major international human rights bodies to constitute a form of torture. This is the position, for example, 
of the Istanbul Statement on the Use and Effects of Solitary Confinement (2007); the UN Basic Principles for the Treatment of Prisoners (1990); and the UN Convention Against Torture and Other Cruel, Inhuman or Degrading Treatment or Punishment (1985). As recently as August of 2013 the United Nations Special Rapporteur on torture issued a statement equating prison isolation with torture, stating, "Even if solitary confinement is applied for short periods of time, it often causes mental and physical suffering or humiliation, amounting to cruel, inhuman or degrading treatment or punishment" (Miles, 2013).

The origins of solitary confinement, however, belie such violence, at least in their initial intentions. Developed at the turn of the 19th century as the central architecture of the emergent penitentiary system, the cellular isolation of prisoners was first championed as an enlightened, humanist corrective to pre-existing punishment practices, such as public beatings, hangings and other corporeal brutalities. The first institution in the US to experiment with isolation was the Walnut Street Jail in Philadelphia, built at the end of the 18th century by members of the Quaker Church with the objective not just of punishing criminals but also of rehabilitating them. The model was quickly adopted by the original American penitentiaries, first in Philadelphia at Eastern State and then in Auburn, New York at the beginning of the 19th century (Smith, 2009).

The solitary confinement cell was central to these early experiments with the penitentiary form because isolation was coterminous in the minds of reformers with the idea of imprisonment as a socially productive system of punishment. In the one-man cells and total silence in which felons spent their days and nights, it was believed, they would discover inside of themselves the requisite remorse and self-realization to become not just better people, but true citizen-subjects. "Through the reflection that it gives rise to and the remorse that cannot fail to follow," describes Foucault in his foundational genealogy of Western penal systems, "solitude must be a positive instrument of reform" (1977: 237). Our jails are called penitentiaries because of this penitence that solitude was meant to occasion.

The idea, at the time, was a revolutionary one. That criminals could be rehabilitated and reformed was an untested idea in the history of penology, and spoke to a particular kind of humanism popularized during the early Enlightenment period. This is an era that witnessed a radical shift in the dominant conception of the individual subject. With the rise of the bourgeoisie and early industrial capitalism in the 18th and 19th centuries, the individual, now the bearer of formal rights and liberties, came to be regarded as responsible for his own place in the social system (Davis, 2003; Smith, 2009; Wood, 1995). The role of this emergent individual subject to the restructuring of the modern social, political and economic order is significant, and will be elaborated upon later in this article. Certainly, the idea of the self-governing subject bore itself out in the early experiments with the prison, whose champions held that discipline should not just harm the offender but also improve him (Smith, 2009). The prison really was to be a "house of corrections," one within which a remade citizen-subject, newly capable of the rigors of selfdiscipline, would emerge from the seclusion of the solitary cell (Smith, 2009: 10).

Contrary to the humanist ideals that at least partly animated the prison's early champions, however, total isolation, rather than offering criminals the requisite conditions of selfreflection to rehabilitate them into ideal subject-citizens, instead drove prisoners $\mathrm{mad}$. Evidence to this effect abounded throughout the 19th century. As early as the 1830s, reports had started to materialize about the various mental disorders isolated prisoners were exhibiting. These included hallucinations, "dementia, and "monomania" (Smith, 2006: 457). Charles Dickens, indulging Europe's interest in this radical experiment in criminal justice by visiting the isolation cells at Eastern State Penitentiary in 1842, wrote of his shock at meeting sense-deprived and wild-eyed prisoners. They were "dead to everything but torturing anxieties and horrible despair," he wrote, concluding, "I hold this slow and daily tampering with the mysteries of the brain to be immeasurably worse than any torture of the body" (Dickens, 1957: 99).

German doctors documented a spike in psychosis among prisoners in their isolationist replicas of the Pennsylvania model, and clinical research reports across Europe were unequivocal about the dire psychological effects of total solitude. By the late 1800s the concept of total isolation had been thoroughly discredited, even evoking condemnation by the US Supreme Court. In an 1890 opinion concerning the effects of solitary confinement on prisoners in Philadelphia, US, Supreme Court Justice Samuel Freeman found that "a considerable number of prisoners fell ... into a semi-fatuous condition ... and others became violently insane" (quoted in Biggs, 2009). As a system of penal practice solitary confinement was officially abandoned in 1913, and retreated, for more than half a century, from common use.

\section{Solitary confinement redux: the rise of the supermax and the general demolition of the person}

Beginning in the 1960s and proliferating most systematically over the last 30 years, we have seen a revival of the practice of solitary confinement in the United States as an increasingly long-term and wide-reaching practice. Since the early 1980s, the use of isolation has come to be one of the fastest-growing conditions of detention, even exceeding the expansion of the US prison system in general over the same period. For example, while the overall prison population increased by $28 \%$ from 1995 to 2000, the number of US prisoners in solitary grew by $40 \%$ during that time (Johnson, 2010). This expansion has occurred most systemically under the aegis of the supermax prison, and in the design and construction of prison 
control units more generally. Massive, highly technologized, and largely impenetrable to members of the public, supermax prisons are specifically designed for the prolonged and often indefinite isolation of prisoners classified as high risk and/or difficult to control (Rhodes, 2009; Shalev, 2011). Control units, likewise, are the designate part of a prison that operates under a "super-maximum security" regime, and share with supermaxes the indefinite lockdown of prisoners in isolation for $22-23 \mathrm{~h}$ a day. The institutional designation of a prisoner into solitary confinement, meanwhile, is an administrative rather than judicial decision, and one made by corrections management and officers in a whole host of scenarios. Supermax prisoners are often described by prison officials as the "worst of the worst," a discourse perpetuated within official justifications for the increased need for supermax units despite being an amorphous and discretionary category with no clear accompanying criteria (Rhodes, 2009: 196).

The literature investigating the precise purpose of solitary confinement, meanwhile, despite its massive costs and deleterious effects on prisoners' mental health, is still sparse (King, 1999; Mears and Reisig, 2006: 34). Within the scholarship that does exist, Lorna Rhodes (2004) has provided one of the few ethnographic accounts of life inside a supermax unit. Other accounts have sought to trace the judicial negotiation buffeting the supermaxes' rise, and the degree to which courts have deemed isolation units compatible with the constitutional rights of prisoners and detainees (Shalev, 2011; Reiter, 2012). There has also been some important work documenting how isolation and sensory deprivation were initially used in the 1960s as a technique of "behavior modification" and protest management against politicized and politically active prisoners in particular, including Black Muslims, jailhouse lawyers, and those identified with various radical freedom struggles of the period (see Gomez, 2006). In general, however, most accounts (Shalev, 2009; King, 1999; Kurki and Morris, 2001; Ward and Werlich, 2003) tend to offer descriptive accounts of the physical structure, day-to-day operations, or narrative history of the supermax phenomenon, alongside only brief speculation into the functional origins and purpose of the control prison in the contemporary period.

What is not fully understood about why solitary confinement has proliferated so systematically over the past thirty years is counterbalanced by an abundance of literature attesting to its effects on prisoners themselves. In other words, what is known for certain is that under the conditions of deprivation of human contact and extremely restricted sensory stimulation that characterizes standard practices of solitary confinement in Western liberal democracies (Shalev, 2011:153), the human self is unlikely to psychologically survive.

In a series of interviews I conducted with two dozen exprisoners who had spent more than 6 months in solitary confinement, the words that came up over and again were "broken," "insanity," "lost," "closing of mind," and "living death."
One ex-prisoner described the mental place he found himself in after many months in isolation as a state of losing oneself: "That wall that I built there, in reality, is destructive, because I can't move out of that ... for those who can't get that back, they're lost forever. And you get a lot of suicides as a result of this stuff, because they just lose themselves." He characterized that fight as a battle between normality and insanity, and compared the condition of total isolation to a kind of death. "It's a dead space. That's probably the best way I can describe it, because it only is relevant to you, experiencing what you're experiencing at the time, but it makes no sense to nobody else. It's like a void."

Another prisoner describes feeling acutely damaged by the 11 years she spent in and out of isolation, even 12 years after her release from prison. "Solitary confinement does drive you insane. In solitary it's not just a loneliness, it's a craziness. Because it's what you have in your mind to begin with that can help you, or hurt you. There's no external stimulation. Everything is the same. So, it's a devastating experience."

Indeed, the effects of long-term solitary confinement on a prisoner's mental health have proven to be uniquely damaging. Among the most extensive and groundbreaking of the research on the psychological consequences of solitary confinement is a 1982 study of isolated prisoners conducted by Dr. Stuart Grassian, a psychiatrist at Harvard University Medical School and an expert on the psychological impact of control units. He found that "solitary confinement itself can cause a very specific kind of psychiatric syndrome, which in its worst stages can lead to an agitated, hallucinatory, confusional psychotic state often involving random violence and self-mutilation, suicidal behavior, [and other] agitated, fearful and confusional kind of symptoms" (quoted in Kamel and Kerness, 2003: 3). He termed this condition "SHU syndrome" after the "secure housing unit," the prison system's favored terminology for the modern solitary cell. In his extensive and groundbreaking 1982 study of isolated prisoners he delineates a particular cluster of symptoms produced by long-term segregation, grouped into the six basic components that make up the SHU syndrome: (1) hypersensitivity to external stimuli; (2) perceptual distortions, illusions, and hallucinations; (3) panic attacks; (4) difficulties with thinking, concentration, and memory; (5) intrusive obsessional thoughts; and (6) overt paranoia (Grassian, 2006: 337).

Grassian's research offers the most extensive and detailed reports of prisoners' first-person testimony, but his findings are consistent with most other studies that document the detrimental psychological impacts of long-term solitary confinement (also see Kupers, 1999; Haney and Lynch, 1997; Haney, 2003). Under these conditions, it is evident, prisoners lose not only their sense of the distinction between reality and hallucination, but they seem to descend into a generalized confusion and cognitive impairment that violently dissolves one's very sense of personhood.

Common within the testimonies and observations of solitary confinement's effects across both the 19th and 20th cen- 
turies is an overwhelming sense of isolation's damage, even violence, on its subjects. Of particular note is the way its consequences are felt not on the tissue of the body per se, but as operating at a more general and fundamental level of a person's being. In Dickens' vivid notes, the damage he observed seemed to occur as if at the register of personhood itself. As the phenomenologist Lisa Guenther, reading Dickens, puts it, the withdrawal from concrete relations with others constituted a violence that "leaves no bruises, and yet it effects a general demolition of the person" (Guenther, 2013: 19). It is to what this "general demolition of the person" tells us about the individual subject itself that we now turn.

\section{4 "A recoding of existence": isolation and the individual}

While the experiment with solitary confinement as a mechanism for humanistic rehabilitation in the 19th century had clearly been a disaster, the relationship between the space of the solitary prison cell and an emergent ontology of the individual subject proved to be a mutually productive and enduring one (Foucault, 1977; Smith, 2009). Indeed, Foucault characterizes the institutionalization of subject production pioneered through the prison edifice as "a recoding of existence," the first principle of which was isolation: "The isolation of the convict from the external world, from everything that motivated the offence, from the complicities that facilitated it. The isolation of the prisoners from one another. Not only must the penalty be individual, but it must also be individualizing" (italics added, Foucault, 1977: 236).

The production of the atomized individual was central to a whole host of political and economic transformations taking place during this period. In his history of the solitary cell the literary scholar Caleb Smith (2009) underscores the centrality of cellular isolation to the 18th century projects of nation-building, capitalist industrialization, and liberal subject production. The isolation cell, he argues, was tactically effective in that it allowed authorities to disperse and manage the prison population, but it also deeply aligned with, and reinforced, the dominant culture's evolving common sense about the autonomous character of the human subject and the individualized responsibilities of the rights-bearing citizen (Smith, 2009). The prisoner in solitary was not just a transgressive self, in other words, he was an ideal self.

Foucault similarly interprets the prison not simply as a space to contain problematic bodies, but as a tactic, one used to reproduce state power and produce particular kinds of political subjects - both inside and outside of the prison. "Penal imprisonment," Foucault reminds us, "from the beginning of the nineteenth century, covered both the deprivation of liberty and the technical transformation of individuals" (1977: 233). Solitary confinement enacts, or attempts to enact, a total realization of this disciplinary power.
Yet if Foucault saw the prison as a disciplinary edifice for the production of certain kinds of subjects, others have suggested that the prison's spatial power resides just as much in its destructive capacity and divestment of subjecthood.

Colin Dayan's work (2007) investigates the historical centrality of the concept of "civil death" - a legal fiction indicating the status of a person who has been deprived of all civil rights - to the laws governing the status of the prisoner. In the US, civil death statutes have dictated that the felon may not vote or make contracts, loses his property, and in some states "widows" his wife. Thus the convict retains his or her "natural life" but has lost the higher, more abstract, civil life that made him/her fully human in the eyes of the law (Dayan, 2007). Caleb Smith elaborates on Dayan's work to argue that civil death is the legal language that finds its "materialization" in the modern prison. Evidence amassed from the earliest penitentiaries reveal a reality not of rebirth or rehabilitation, but (using the idiom often invoked) a kind of death-in-life; a living death. Contrary to the ambitions of the 18th century humanists and industrialists alike, the conditions of solitary confinement did not generate improved and productive ideal subjects for the emergent capitalist nationstate. Rather, as Gustave de Beaumont and Alexis de Tocqueville in their 1833 report on the American penitentiary put it: "Absolute solitude ... destroys the criminal without intermission and without pity; it does not reform, it kills" (quoted in Smith, 2009: 67).

This violently destructive capacity derives from the unique power of social and spatial isolation to damage a prisoner's very capacity to function as a willful human being. Guenther makes just such a point, drawing specifically from the field of phenomenology as well as the psychological literature documenting the deleterious effects of isolated confinement on the psyche, to suggest that when studied together, they make a strong case against the ontology of a self-contained subject. She asks, "What must a person be like, in order for this destruction to be possible?" (2013: 22). She concludes, convincingly: "These transformations are only possible if the person in solitary confinement is not simply an atomistic individual, separable from others and from the world, and constructed of different interlocking but separate parts" (2013: 20).

Indeed, the consistency with which prisoners become unhinged in various ways from reality when deprived of everyday encounters with sentient beings and sensorial stimulus demonstrates that "full, concrete personhood is structurally undermined in prolonged solitary confinement" (Guenther, 2011: 262). For solitary confinement to break people apart in the way that Dr. Grassian's study of isolated prisoners and most other comprehensive psychological research - suggests it does, Guenther argues, subjectivity itself must be constituted relationally. In other words, its violence is enacted against the social structures that make a particular way of being possible in the first place - the very relationality that constitutes subjecthood itself. 
Solitary confinement enacts a fundamental and existential violence on those subject to its practice. That this violence is enacted against the experiential structures that make possible a functional being, itself stands as a powerful reason for a political or ethical critique of solitary confinement as a penal practice. It is important to also point out, however, that while violence might characterize the ends, individuation defines the means. Appreciation of the violence inherent to this particular practice, therefore, necessarily holds transferable implications for a critical reassessment of any or all socially isolating institutions and individuating ideologies within the structural fabric of modern life. If solitary confinement confirms anything to us, it is that the individuated subject is a broken, even impossible self. Such a self, moreover, stands in remarkable contrast to the ideal of the self-contained and self-determining subject we are, in modern life, expected to become.

\section{Individuation and its discontents}

Escaping into individual solitude has had a long association with intellectual and spiritual well-being, at least within the modern period. Jean-Jacques Rousseau would, influentially, develop a whole political philosophy out of the idea of a nature inside, even making a point to practice solitude as part of his regime of self-regard: "[During] my solitary walks and the reveries that occupy them," he wrote, "I give free rein to my thoughts and let my ideas follow their natural course, unrestricted and unconfined. These hours of solitude and meditation are the only ones in the day when I am completely myself and my own master, with nothing to distract or hinder me, the only ones when I can truly say that I am what nature meant me to be" (Rousseau, 1979: 35).

At the same time that the earliest experiments with penal isolation were being discredited as a rehabilitating method, the idea of the atomistic individual underlying this early 19th century project remained a salient organizing force, one that retains potency and influence in most other aspects of contemporary Western life. The notion that isolation could offer prisoners relief from a corrupt external world and a salvation in a retreat inwards is expressive of a philosophy of subjectivity that presupposes the individual as such; the concept of the individuated subject. This contemporaneous ontology, itself a radical departure from previous conceptions of selfhood, has proven far more enduring than the penal idealism that justified the first experiments with prison isolation. Insofar as solitary confinement has in its more recent revival been relieved of its rehabilitative narrative, moreover, it might now be seen as existing as counterpoint rather than corroborative to the idea of the self-contained individual being; the violence of isolation giving lie to the very ontology of the individual subject. The idea of that individual being, however, holds stronger than ever.
Outside the cellular and segregated walls of the 19th century prison's solitary architecture, modern life reverberates with analogous themes: the psychology of private consciousness; the celebration of individual responsibility and selfdetermination in economic and political behavior; the innate rights of humans mobilized as the basis for justice struggles. Indeed, the value Western society places on individual experience shares an intimate relationship with the political and economic systems that organize political democracy in the contemporary West, specifically liberal capitalism. Liberalism as a system and an ideology takes atomistic individuals as the basic units of political and legal theory (Cairns and Sears, 2012: chap. 3; Wood, 1995). The liberal vision of human beings as self-made and self-determining is foundational to the theories of liberty championed by liberalism's earliest philosophers, from John Locke to John Stuart Mill, and more recent heirs, such as Isaiah Berlin and John Rawls (Nedelsky, 1989: 8). The premise is the same: the individual as a self-contained, autonomous, and atomized being. The history of this ontology, however, is a relatively modern one.

The individual as we conceive of it in the West today began to take shape in the 17 th and 18 th centuries, and one finds some of its earliest theoretical justification in the writing of French philosopher René Descartes. The thinker, mathematician and writer would become famous for developing the philosophical basis for distinguishing between the nonmaterial mind and the material body, known as Cartesian dualism. The Cartesian model, in turn, can be considered essential for understanding the ideology of the modern world.

In his Meditations on First Philosophy, Descartes employs a method called metaphysical doubt in order to reject all that in the world of experience whose existence is predicated on the senses. "I resolved to pretend that all things that had ever entered my mind were no more true than the illusions of my dreams" (quoted in Negri, 2007: 171). All that is left after the dismantling of the world through radical doubt is the " $\mathrm{I}$ " - a realm of reality that is interior, solitary, and superior to the doubtable, and therefore fallible, world of experience "outside" the self. Descartes' famous formula "I think, therefore I am" served as foundation for a metaphysics in which the ego, or the "I" was central. This logic of separation and isolation is foundational to subsequent political theories predicated on individual authority and the supremacy of human reason.

What Descartes offered was not just a novel notion of being, but an understanding of the being of politics in a radically new sense. Antonio Negri suggests that its endurance is "linked to the power of the implicit political dispositif within its author's ontology" (2007: 318). The self-limitation and autonomy of the subject became foundational to a new order and to that effect Descartes' thought has proven to be spectacularly influential on subsequent centuries of Western philosophy and political organization.

In the late 18th century, during the flurry of intellectual, scientific and cultural creativity known as the Enlighten- 
ment, the model of selfhood offered by Cartesian dualism would be taken up and invested with idealistic promises of human betterment and liberty. In the service of the Enlightenment's twin ideals of human emancipation and selfrealization, David Harvey notes, "the "voice of nature within us' becomes a key component of action and understanding" (1996: 122). As described earlier, these ideals were also an important part of the complex rationale animating the prisons' earliest American champions (Smith, 2009). The Enlightenment era therefore not only marked a massive subjective turn, such that we have come to think of ourselves as beings with inner depths, but the conception of liberation that identifies the human individual as the primary locus and the central unit of analysis which persists today.

We do not need to look far to see how the ontology of individuated subjectivity informs the most basic organizing structures of contemporary life. One of the best examples is the regime of private property, rooted in a legal and political ideology that identifies autonomy with a private sphere defined and bounded by property ownership (Nedelsky, 1989: 17; Blomley, 2004). Liberal democracy itself takes as its central premise the primacy of individual rights, the exercise of those rights through representative political systems and their protection from government power. Such is the basis of the social contract as proposed by Thomas Hobbes and John Locke. Individualized self-realization has also been mobilized under capitalism through market choice, which, in turn, derives legitimacy from its presumption of the self-interested individual, homo economicus, exercising free will through practices of consumption and capital accumulation (Harvey, 1996).

We might add to this brief survey the salience in Western society of psychology and psychoanalysis over the past 2 centuries, and their related practices and institutions. As Richard Sennett notes, "The advent of modern psychology, of psychoanalysis in particular, was founded on the faith that in understanding the inner workings of the self sui generis, without transcendental ideas of evil or of sin, people might free themselves from these horrors and be liberated to participate more fully and rationally in a life outside the boundaries of their own desires" (1976: 5). Reflecting on the impoverishment of public and social life consequent to this turn inwards, he writes: "The psyche is treated as though it has an inner life of its own ... each person's self has become his principal burden; to know oneself has become an end, instead of a means through which one knows the world" (Ibid: 4).

It is important to remember that the idea of an inner, individuated self that so permeates modern life has never been ceded as uncontested terrain. As early as the 17th century, writing against Hobbes and other thinkers of the liberal tradition who would have us suppose ourselves "a kingdom within a kingdom ... and is determined by no other source than itself" (quoted in Montag, 1995: 68), Baruch Spinoza argued passionately for a conception of the soul, or the mind (the mens), as contiguous with the activity of the organic body. For Foucault as well, as Warren Montag reminds us, "The individual does not pre-exist his or her interpellation as a subject but emerges as a result of strategies and practices of individualization" (1995: 75). As such a strategy, then, we might do well to think of solitary confinement through this concept of interpellation, and reflect on the possible ontologies of subjectivity its practice reveals, as well as repudiates.

An oft-cited New Yorker article on solitary confinement by the physician Atul Gawande begins with a bold claim: "Human beings are social creatures. We are social not just in the trivial sense that we like company, and not just in the obvious sense that we depend on others. We are social in a more elemental way: simply to exist as a normal human being requires interaction with people" (2009). But how widespread is this particular conception of subjectivity? One might counter that, actually, the prevailing Western orthodoxy of human sociality supposes humans to be, in fact, social only in the sense that we like company and that we depend on others. I posit that this orthodoxy, moreover, operates as structuring corollary to the more salient ontological presumption: that humans are self-contained, separate and individualized beings.

There is a difference between considering humans social in a relational sense - that individuals will and should encounter one another - and considering the social as a constitutive force on being itself, namely that there are no human beings in the absence of relations with others. That we take our being in part from those relations runs counter to a liberal theory concerned primarily with the proper rules governing the interaction among people. The existence and interaction of others is a given, but only insofar as liberal politics is concerned with "drawing boundaries around the sphere of individual rights to protect those individuals from the intrusions of others (individuals or the state)" (Nedelsky, 1989: 9). Not only are rights and responsibilities individual, under liberalism, but they must also be individualizing.

An ontology that instead presupposes that a person's very being is in large part constituted by her interactions with others, that there is no "subject" to protect within a sphere segregated from all others because there is no pre-existing, unitary self in isolation from relationships, has little resemblance to the received notion of individuated selfhood, expressed and reified by the structures, rituals, institutions, discourses and markets that actually organize and govern our lives. An exception, as this paper argues, can be found in the practice of solitary confinement, which in its attempt to realize individuation spatially and materially reveals both its violence, and its impossibility.

It is remarkable how much like Descartes' theoretical exercise in metaphysical doubt the material practice of solitary confinement is. His was essentially a thought experiment in which he identified all that which was known to him solely through sensory experience, and then rejected the reality of those things on the basis of the unreliability of perception. What he believed himself to have been left with was himself, 
alone inside: the I who thinks. The conclusion, as Negri puts it, was that "The individual discovers his own true reality only through isolation" (2007: 180).

Descartes' thought experiment has become our social experiment. From the beginning, control units have relied on actual sensory deprivation. Prisoners are confined in cells rarely larger than a parking space. Few have windows and there is no way of telling whether it is daytime or nighttime. The cells are soundproof. The experience of isolation is meant to be total, such that as little as possible is perceived or received as experiences of the senses. The prisoner in solitary confinement too, finds himself alone, inside. But in stark contrast to Descartes' ostensible revelation of selfhood, the confined prisoner experiences his self, instead, actually disintegrate.

The implications of this contrast - one, indeed, revealing the lie of the other - are significant. For if we are to consider the self isolated and individuated under conditions of solitary confinement to be subject to a kind of violence, then we might consider how other practices of individuation structured by modern life might also constitute violence. The violence extends necessarily into the social and political realms as well as the psychological, and in non-carceral life as well as within the space of the prison. The measurement of life in individualized terms, whether we call this individuality "psychology" or "humanity" has so come to define social relations, that social meanings are themselves generated by the feelings of individual human beings. In that way they serve to effectively mask social relations and inequities of power inherent therein (Sennett, 1976: 337).

Solitary confinement, while extreme, shares defining characteristics with other spaces, structures, and modes of organization familiar to Western society. This is by no means to suggest an equivalency between the deeply racialized and classed experiences of state violence enacted by the solitary confinement cell - experiences that too often culminate in premature death - and the forms of individuation experienced outside the prison. It is rather to suggest that the shared logics and homologies that circulate between such sites also reveal the interplay between power and violence at work in all spaces and practices of individualization organized in everyday life, and therefore also warrant radical critique. That such critique might upset our very ideas about what it means to be human is part of its implicit threat, as well as its potential promise.

\section{Conclusions}

The largest and most sustained contestations of the US prison regime in recent years have come from within the isolation cell. California's third hunger strike in 2 years, originating from the bowels of the Pelican Bay SHUs, came to an end in September of 2013. At its height there were more than 30000 prisoners participating. Since then there have been at least two other hunger strikes waged by prisoners across the country protesting, most immediately, their isolated confinement. One of the latest began on 15 January 2014, when prisoners in the High Security Unit at Menard Correctional Center in Illinois began a hunger strike to protest their indefinite placement in solitary confinement without notice, reasons, or hearings (Lynd and Lynd, 2014).

The core suggestion of this paper is that our reflection on the meaningfulness of their austere spatial conditions on the inside has important implications for thinking about what Dostoevsky might call "civilization" on the outside. We are inheritors of the Enlightenment tradition and we continue in many ways to reinscribe, as a society, Descartes' formulation of dualism, perhaps more intensely than ever under the neoliberal form of social organization. Two key insights follow: first, the concept of the atomistic individual with which we are all familiar is by no means historically given, politically neutral, or ontologically uncontested. Second, it is difficult in modern life to organize ourselves politically or economically or socially in forms other than those premised on individuated subjectivity.

It is tragically ironic, therefore, that people are imprisoned when they fail to live up to the expectations of a modern society and capitalist economy premised on notions of individual will and responsibility, and are then punished with the actuality of that individuation on the other side. The violence might thus be said to begin before one's arrival at the prison gates. If we consider solitary confinement as both a realization of individualism and also as a form of violence enacted against those it subjects, then we must consider the damage done to us by those other dispositifs of modern life that also serve to contain and confine us, alone, inside.

What the lives of prisoners in solitary confinement teach us is that individuated humans are first and foremost inadequate; they do not contain within themselves sufficient content or sufficient being with which to provision their lives. Foreclosure of the social environment from which we draw necessary sustenance thus constitutes a violence on subjecthood itself. The purpose of this paper is also to suggest that solidarity with these isolated prisoners requires identifying ourselves - those of us on the "outside" - with their struggle, and recognizing the shared (albeit unequally so) social conditions and relations that organize the prison regime and life under the neoliberal carceral state more broadly. Indeed, if the solitary confinement cell has always told us something about the condition of modern life and the production of the subject, its contemporary practice should serve as a powerful forewarning about the political work of isolation and individuation as practiced and spatialized outside of prisons as well.

Acknowledgements. I am indebted to James Cairns, Deborah Cowen, Matt Farish, Philip Goodman, and Susan Ruddick for their incisive feedback and support during various stages in 
the writing of this article. I would also like to thank the anonymous reviewers for their generous and extremely helpful comments.

Edited by: J. Turner

Reviewed by: three anonymous referees

\section{References}

Blomley, N.: Unsettling the City: Urban Land and the Politics of Property, Routledge, New York, 2004.

Biggs B. S.: Solitary Confinement: A Brief History, Mother Jones, available at: http://motherjones.com/politics/2009/03/ solitary-confinement-brief-natural-history (last access: May 2014), 2 March 2009.

Briggs, C. S., Castellano, T. C., and Sundt, J. L.: The Effect of Supermaximum Security Prisons on Aggregate Levels of Institutional Violence, Criminology, 41, 1341-1376, 2003.

Brook, D.: A History of Hard Time, Legal Affairs, available at: http://www.legalaffairs.org/issues/January-February-2003/ review_brook_janfeb2003.msp (last access: 10 May 2014), January/February 2003.

Cairns, J. and Sears, A.: The democratic imagination: Envisioning popular power in the twenty-first century, University of Toronto Press, Toronto, 2012.

California Assembly Public Safety Committee Hearing, Testimony on the California Department of Corrections and Rehabilitations Proposed Reforms to the Security Housing Units, available at: http://solitarywatch.com/wpcontent/uploads/2012/ 06/PSHEARINGTRANSCRIPTfeb252013FINAL.pdf, 2013.

Casella, J. and Ridgeway, J.: No Evidence of National Reduction in Solitary Confinement, Solitary Watch, available at: http://solitarywatch.com/2010/06/15/ no-evidence-of-national-reduction-in-solitary-confinement/ (last access: 10 May 2014), 15 June 2010.

Casella, J. and Ridgeway, J.: Unlock the Box: The Fight against Solitary Confinement in New York, The Nation, 2 October 2012.

Davis, A.: Are Prisons Obsolete?, Open Media, New York, 2003.

Dayan, C.: The Story of Cruel and Unusual, MIT Press, Boston, 2007.

Emerson, R. W.: The Conduct of Life, Penguin, New York, NY, 1860.

Foucault, M.: Discipline and Punish: The Birth of the Prison, translated by: Sheridon, A., Vintage, New York, NY, 1977.

Garland, D.: The Culture of Control: Crime and Social Order in Contemporary Society, University of Chicago Press, Chicago, 2001.

Gawande, A.: Hellhole, The New Yorker, available at: http://www. newyorker.com/reporting/2009/03/30/090330fa_fact_gawande (last access: 10 May 2014), 30 March 2009.

Gibbons, J. J. and de B Katzenbach, N.: Confronting Confinement: A Report of the Commission on Safety and Abuse in America's Prisons, Vera Institute of Justice, New York, NY, available at: www.prisoncommission.org/pdfs/Confronting_Confinement. pdf (last access: 6 September 2013), 2006.

Gilmore, R. W.: Golden Gulag: Prisons, Surplus, Crisis, and Opposition in Globalizing California, University of California Press, Berkley, CA, 2007.

Gómez, A. E.: Resisting Living Death at Marion Penitentiary, 1972, Radical Hist. Rev., 96, 58-86, 2006.
Gottschalk, M.: The Prison and the Gallows: The Politics of Mass Incarceration in America, Cambridge University Press, Cambridge, 2006.

Grassian, S.: Psychiatric effects of solitary confinement, Journal of Law and Policy, 22, 325-383, 2006.

Guenther, L.: Subjects Without a World? An Husserlian Analysis of Solitary Confinement, Hum. Stud., 34, 257-276, 2011.

Guenther, L.: Solitary Confinement: Social Death and its Afterlives, University of Minnesota Press, Minneapolis, MN, 2013.

Haney, C.: Mental health issues in long-term solitary and 'supermax' confinement, Crime Delinquency, 49, 124-156, 2003.

Haney, C. and Lynch, M.: Regulating prisons of the future: Psychological analysis of supermax and solitary confinement, New York University Review of Law \& Social Change, XXIII, 4, 477-570, 1997.

Harvey, D.: Justice, Nature and the Geography of Difference, Blackwell, Oxford, 1996.

Horton, S.: Bush and the Art of Breaking Human Beings, Harpers, available at: http://www.harpers.org/archive/2007/08/ hbc-90000901 (last access: 10 May 2014), 15 August 2007.

Human Rights Watch: Long-Term Solitary Confinement of Political Prisoners, Human Rights Watch, available at: http://www.hrw. org/en/node/12007/section/9 (last access: 10 May 2014, 2004.

Johnson, K.: States Start Reducing Solitary Confinement to Help Budgets, USA Today, available at: http://www.usatoday.com/ news/nation/2010-06-13-solitary-confinement-being-cut_N. htm (last access: 10 May 2014), 14 June 2010.

Kamel, R. and Kerness, B.: The Prison Inside the Prison: Control Units, Supermax Prisons, and Devices of Torture: A Justice Visions Briefing Paper, American Friends Service Committee, Philadelphia, PA, 2003.

Kupers, T.: Prison Madness, Jossey-Bass, San Francisco, 1999.

Kuriki, L. and Morris, N.: The Purposes, Practices and Problems of Supermax Prisons, Crime and Justice: A Review of Research, edited by: Tonry, M., University of Chicago Press, Chicago, 2001.

Lynd, A. and Lynd, S.: Illinois prisoners in Menard High Security Unit plan to begin hunger strike Jan. 15, San Francisco BayView, available at: http://sfbayview.com/2014/illinois-prisoners-inmenard-high-security-unit-plan-to-begin- hunger-strike-jan-15/ (last access: 10 May 2014), 14 January 2014.

Mauer, M.: Race to Incarcerate, revised edition, The New Press, New York, 2006.

Mears, D. P. and Reisig, M. D.: The theory and practice of supermax prisons, Punishment \& Society, 8, 33-57, 2006.

Miles, T.: U.N. expert says solitary confinement in U.S. prisons can be torture, Reuters, available at: http://www.reuters.com/article/2013/08/23/ us-usa-california-torture-idUSBRE97M0QU20130823 (last access: 10 May 2014), 23 August 2013.

Montag, W.: The Soul is the Prison of the Body, Yale French Studies, 88, 53-77, 1995.

Nedelsky, J.: Reconceiving Autonomy: Sources, Thoughts and Possibilities, Yale Journal of Law and Feminism, 1, 7-36, 1989.

Negri, A.: Political Descartes: Reason, Ideology and the Bourgeois Project, translated by Mandarini, M. and Toscano, A., Verso, New York, 2007, 1970.

Perkinson, R.: Texas Tough: The Rise of America's Prison Empire, Metropolitan Books, New York, 2010. 
Rhodes, L. A.: Total Confinement: Madness and Reason it the Maximum Security Prison, University of California Press, Berkeley, CA, 2004.

Rhodes, L. A.: Supermax as a Technology of Punishment, Soc. Res., 74, 547-566, 2007.

Rhodes, L. A.: Supermax prisons and the trajectory of exception, Studies in Law, Politics and Society, 47, 193-218, 2009.

Rousseau, J. J.: Reveries of the Solitary Walker, translated by France, P., Penguin, New York, NY, 1979.

Schaeffer-Duffy, C.: Solitary Confinement: An American Invention, National Catholic Reporter, available at: http://natcath.org/NCR Online/archives2/2000d/112400/112400d.htm (last access: 10 May 2014), 23 November 2000.

Shalev, S.: Solitary Confinement and Supermax Prisons: A Human Rights and Ethical Analysis, Journal of Forensic Psychology Practice, 11, 151-183, 2011.

Sennett, R.: The Fall of Public Man, W.W. Norton, New York, 1976.

Sennett, R.: The Conscience of the Eye, W.W. Norton, New York, 1990.

Smith, C.: The Prison and the American Imagination, Yale University Press, New Haven, 2009.
Smith, P. S.: The Effects of Solitary Confinement on Prison Inmates: A Brief History and Review of the Literature, Crime and Justice, 34, 441-528, 2006.

Sullivan, L.: Timeline: Solitary Confinement in U.S. Prisons, National Public Radio, available at: http://www.npr.org/templates/ story/story.php?storyId=5579901 (last access: 10 May 2014), 26 July 2006.

Thoreau, H. D.: Walden and other Writings, edited by: Krutch, J. W., Bantam, New York, 2004, 1854.

Wacquant, L.: Deadly Symbiosis: When Ghetto and Prison Meet and Mesh, Punishment and Society, 3, 95-134, 2001.

Wacquant, L.: Ordering Insecurity: Social Polarization and the Punitive Upsurge, Radical Philosophy Review, 11, 9-27, 2008.

Wacquant, L.: Prisons of Poverty, University of Minnesota Press, Minneapolis, 2009.

Ward, D. A. and Werlich, T. G.: Alcatraz and Marion: Evaluating Super-Maximum Custody, Punishment and Society, 5, 53-75, 2003.

Wood, E. M.: Democracy against capitalism: Renewing historical materialism, Cambridge University Press, Cambridge, 1995. 